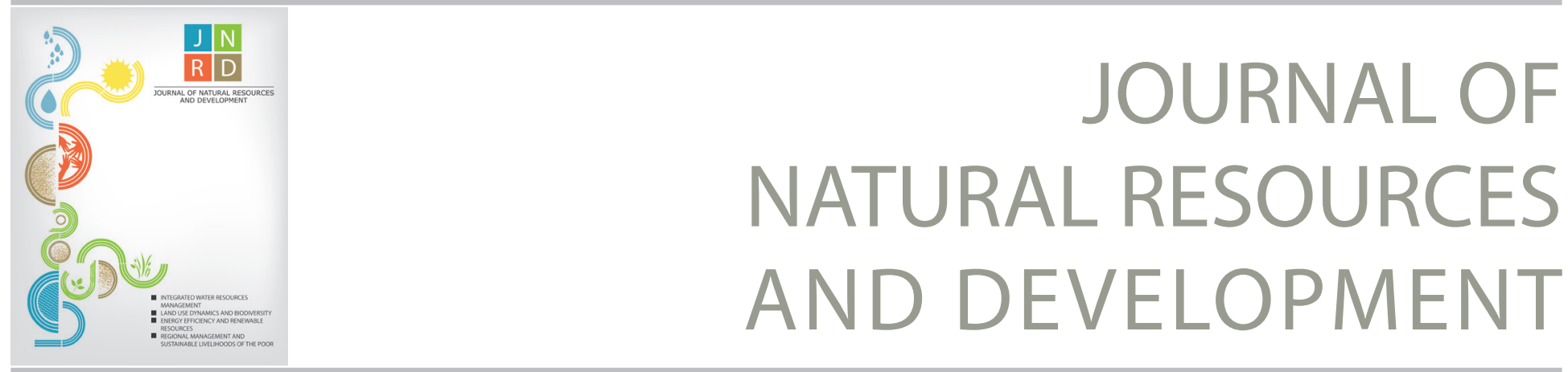

Research article

\title{
Characterization and Mapping of the Causes, Intensity and Effects of Natural Resource Use Conflicts in Kilosa and Mvomero, Tanzania
}

Kassim R. Mussa ${ }^{a *}$, Reuben Mwamakimbullah ${ }^{b}$, Christopher P. Mahonge ${ }^{c}$

a Department of Geography and Environmental Studies, Solomon Mahlangu College of Science and Education, Sokoine University of Agriculture, P.O.BOX 3038, Morogoro, Tanzania

b Department of Forest Product and Technology, College of Forestry, Wildlife and Tourism, Sokoine University of Agriculture, P.O. BOX 3006, Morogoro, Tanzania

Department of Policy Planning and Management, College of Social Sciences and Humanities, Sokoine University of Agriculture, P.O Box 3035, Morogoro, Tanzania

* Corresponding author: kassimr@gmail.com; kassimr@sua.ac.tz

\section{Article history}

Received 04/08/2018

Accepted 13/12/2018

Published 15/01/2019

\section{Keywords}

Natural resource use conflicts

Conflict typology

Conflict intensity

Conflict Analysis

\section{Abstract}

Tanzania has experienced many natural resource use conflicts in many parts of the country, including the Kilosa and Mvomero districts, ranging from family disputes through to all-out social unrest. Despite some efforts to curb rampant natural resource use conflicts, there is overwhelming evidence of the existence and upsurge of such conflicts, leading to various consequences, including death of people involved, destruction of property and the creation of a sense of insecurity. This study aims to characterize and map the causes, intensity and effects of natural resource use conflicts in the districts of Kilosa and Mvomero, Tanzania. Key Informant Interviews were used to gather valuable evidence to characterize the natural resource use conflicts in Kilosa and Mvomero, which also aided in constructing natural resource-use conflict typology. Quantum GIS software was used for spatial mapping of the conflicts. The study confirmed that land, water, crops, pasture and minerals are the main natural resources behind the conflicts, and therefore these resources have to be treated as crucial dimensions of conflict prevention in Kilosa and Mvomero. Generally, there is complexity in the conflict situations and overlapping of causes and conflict types on the one hand, and overlapping of conflict types and resources which are contested for on the other.

(C) 2019 This is an open access article under the CC BY-NC-ND license (http://creativecommons.org/licenses/bync-nd/4.0/). 


\section{Introduction}

\subsection{Background Information and Rationale}

Struggles over access to and control over natural resources quite often lay the grounds for violent conflicts in many places of the world (Benjaminsen \& Bryceson 2012). Arguably, in the last sixty years, at least $40 \%$ of civil wars in the African continent have been connected with natural resources (Matthew, 2008; UNEP, 2009). Since people's relationship to natural resources is incorporated into their social world, conflicts arise due to incompatibility of ideas between two or more parties with regard to the use and control of a particular natural resource (Banks, 2008). According to Humphreys (2005), countries whose economies are largely dependent on natural resources are highly vulnerable to civil violence. To that effect, Tanzania is not free from natural resource-use conflicts.

Natural resource use conflict analysts predict that, if not addressed now, future natural resource use conflicts will likely take the form of resource wars, which are conflicts predominantly waged over access to scarce natural resources such as rare minerals, water, pasture and oil (Humphreys, 2005; Pegg, 2003; Richards, 2001). The fundamental tenet behind this proposition is that, as the global population continues to rise, and hence the demand for natural resources continues to grow, there is significant potential for conflicts over natural resources to intensify (UNEP, 2009). While it is argued that resource abundance and scarcity are the principal causes of violent conflicts, scholars like (Krummenacher, 2008) maintain that in some instances neither scarcity nor abundance can drive a society down the road to violent conflict. In addition, water and land or environmental degradation can be equally important ingredients in a complex blend of political, cultural, and economic factors that eventually breed grounds for fatal conflicts. These arguments show how complex the causes of natural resource use conflicts can be, and so are the solutions.

Tanzania, which is heavily dependent on natural resources for economic growth and the livelihood of many rural and urban communities has experienced many natural resource use conflicts, ranging from family disputes through to all-out social unrest. Despite some efforts to curb rampant natural resource use conflicts, there is overwhelming evidence of the existence, persistence and upsurge of natural resource use conflicts in various parts of the country as reported by Mwanfupe (2015), Kideghesho (2006), Ndelwa (2014), Nkhambaku (2014), Mbonde (2015), Ngowi and Makfura (2015). These conflicts have led and are still leading to various consequences, including the death of people involved (Benjaminsen, Maganga \& Abdallah, 2009), destruction of property (Emanuel \& Ndimbwa, 2013) and the creation of a sense of insecurity, for example, by rendering children unable to attend schools. The conflicts experienced in Kilosa, Mvomero, Kiteto and Kilindi (Benjaminsen, Maganga \& Abdallah, 2009; King, 2013; Massoi, 2015) just to mention a few, are cases in point, which substantiate the aforementioned conflict consequences.

Similarly, there is evidence regarding factors behind natural resourceuse conflicts which are categorized as due to increased human and animal population, natural (e.g. drought and climate change), anthropogenic (e.g. natural resources degradation), conservational (e.g. reservation of land for protected areas), knowledge-related (e.g. vague understanding of existing laws on rights of access to land and other natural resources), governance-oriented (e.g. rent seeking, corruption, and misuse of power), and economic (e.g. competition over natural resources such as timber, minerals, land for large investments, and water for irrigation versus other uses) (Economic Commission for Africa, 2012). As such, due to the diverse nature of the factors, natural resource use conflicts involve multiple diverse sector-players, including farmers, livestock keepers, investors, policy makers and practitioners, thus creating multidimensional conflictual relationships which produce a complex web of relationships that have different spatial and temporal dimensions, characteristics and intensities.

However, unravelling their causality and characterizing natural resource use conflicts require a thorough understanding of the specific ways in which natural resources are constructed, construed, contested for and ultimately accessed in a society. Up to this juncture, it suffices to concede that, natural resource use conflicts in most parts of the country do exist, but characteristics, causes and intensities of the conflicts vary considerably from one place to the other. Kajembe, Mbwilo, Kidunda and Nduwamungu (2009), Kajembe, Silayo, Mwakalobo and Mutabazi (2013) argued that, the intensities, types and levels of many natural resource use-conflicts in Tanzania are poorly known and documented, which makes it hard to design succinct conflict management interventions. Furthermore, Humphreys (2005) opined that, most natural resource conflict resolution research frameworks are poorly developed and thus are inadequate in terms of succinctly assessing and monitoring natural resource use conflicts.

While systematic mapping of various natural resources has been successful in Tanzania and elsewhere in the world, mapping of natural resource use conflicts is a gray research area requiring more attention of natural resource use conflict stakeholders and national governments at large. Thus, unless the characteristics and intensities of natural resource use conflicts are spatially differentiated, unfolded and documented, it is practically impossible to prioritize conflict management interventions and therefore any professional and policy-related discourses regarding causes, intensities and socioeconomic impacts of natural resource-use conflicts in Tanzania will be reduced to mere rhetoric, speculations and perceptions. This proposed study therefore sought to answer the following research questions, (i) how are natural resources constructed, construed, and contested for in Kilosa and Mvomero, and (ii) how can natural resource use conflict be spatially mapped and characterized in the context of causes, intensity, effects and severity? The overall objective of this study is to characterize and map causes, intensity and effects of natural resource use conflicts in Kilosa and Mvomero, Tanzania. Specifically, the study sought to (i) characterize the natural resource use conflicts in Kilosa and Mvomero, (ii) develop a natural resource use conflict severity index and conflict assessment and monitoring framework, and (iii) carry out a spatial mapping of the intensities of natural resource use conflicts across the conflict-prone areas of Kilosa and Mvomero. 


\section{Methodology}

\subsection{Study area description}

This study was carried out in the districts of Mvomero and Kilosa, in the Morogoro region, which have a long-standing history of natural resource use conflicts. Being close to one another, the two districts have had more or less similar types of causes and timing of natural resource-use conflicts. This has captured a lot of stakeholders' interests and attention with regard to how the conflicts unfold, and the underlying causes and effects. Mvomero is located at latitude $06^{\circ} 26^{\prime}$ South and longitude $37^{\circ} 32^{\prime}$ East. It borders the districts of Handeni and Kilindi in the North, Bagamoyo district in the East, Kilosa district in the West, Morogoro district and Morogoro Municipality in the South (Figure 1). The district is characterized by high rainfall between March and May and short rains from October to December when predominantly eastern trade winds bring moisture from the Indian Ocean. Annual rainfall is between $600 \mathrm{~mm}$ and $2000 \mathrm{~mm}$ being lowest at the foothills and highest between $400 \mathrm{~m}$ and 2000 m.a.s.l. The temperature in the district ranges from $18-30{ }^{\circ} \mathrm{C}$. The district occupies a total area of approximately $7,325 \mathrm{~km}^{2}$. The area which is suitable for agricultural activities is 549,375 ha, but only around 45 $\%$ of the area is cultivated. The main crops grown are maize, paddy, beans, horticultural crops in the highlands, cassava and sunflower to mention just a few. The area which is suitable for livestock keeping is estimated to be 266,400 ha. The district is administratively divided into 30 Wards, and a little more than 120 villages.
Kilosa lies between $6^{\circ} \mathrm{S}$ and $8^{\circ} \mathrm{S}$, and $36^{\circ} 30^{\prime} \mathrm{E}$ and $38^{\circ} \mathrm{E}$. It borders the Gairo district to the North and Mvomero district to the east. In the South, it is bordered by the districts of Kilombero and Kilolo (Figure 1). Kilosa comprises mostly flat lowland that covers the whole of the eastern part called the Mkata Plains, and it experiences an average of eight months of rainfall (October-May), with the highest levels between March and May. The rainfall distribution is bimodal in good years, with short rains (October-December), followed by long rains (mid-February-May). Mean annual rainfall ranges between 1,000 and $1,400 \mathrm{~mm}$ in the southern flood plain, while further north has an annual rainfall ranging from 800 to $1,100 \mathrm{~mm}$. The mean annual temperature in Kilosa is about $25^{\circ} \mathrm{C}$. More than $80 \%$ of people in Kilosa and Mvomero depend on agriculture (Kajembe, Silayo, Mwakalobo \& Mutabazi, 2013) and with the varied conditions, ranging from plateaus characterized by seasonally flooded plains to mountainous areas with altitudes surpassing $2000 \mathrm{~m}$, the two districts offer a variety of agro-ecological conditions for farming (Maganga \& Odgaard 2007). A variety of crops is grown including maize, rice, millet, cassava, beans, bananas and cowpeas. Small-scale farming, where the average farmland is less than one hectare represents $90 \%$ of agriculture, with large-scale farming representing the other $10 \%$. The small-scale farm holders are subsistence farmers who produce mostly for domestic use, selling only their surplus. There is a limited use of inputs such as improved seeds, fertilizers and/or manure, and the majority $(95 \%)$ use hand hoes for cultivation (Shishira \& Yanda, 1997).

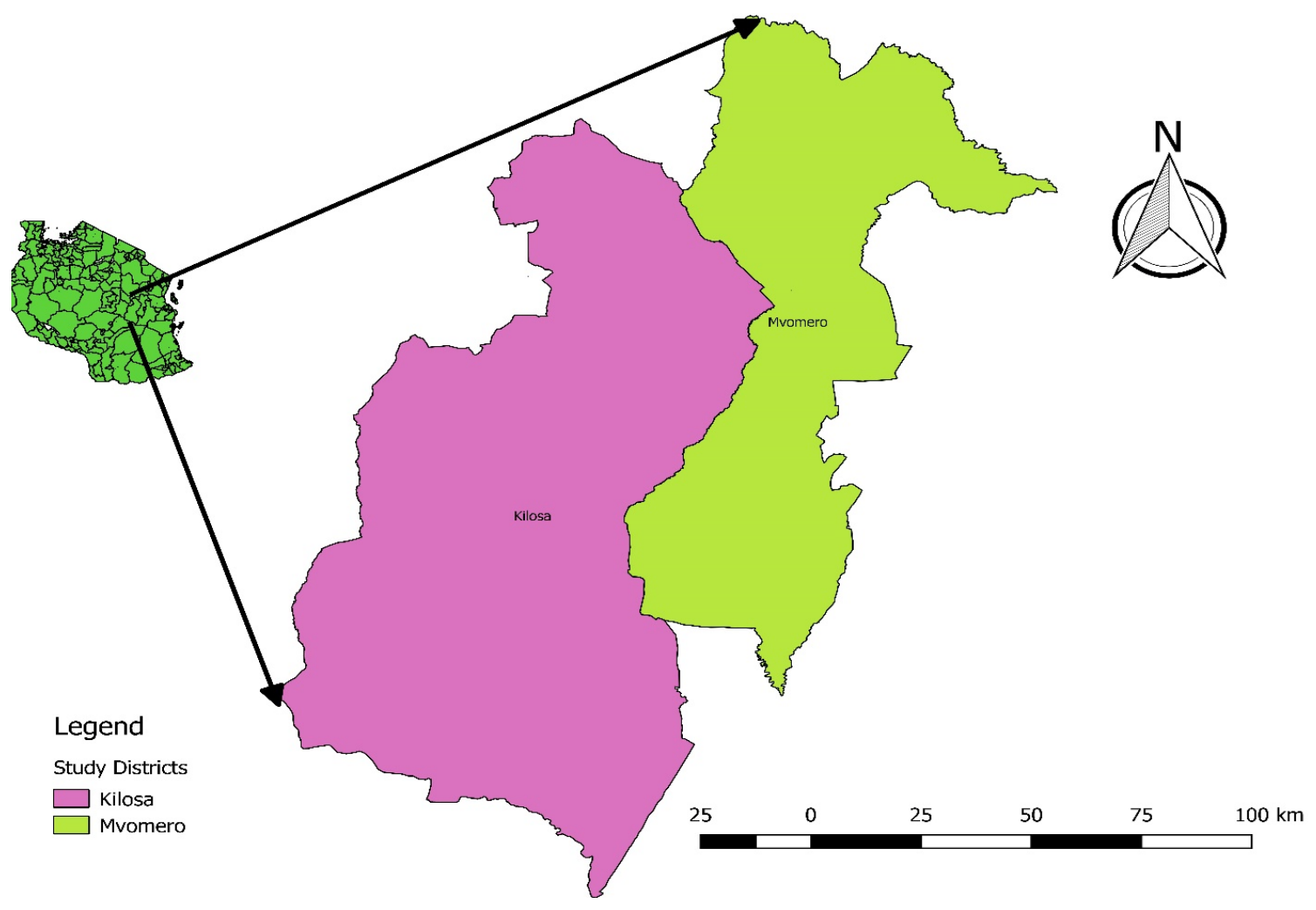

Figure 1: The map showing the location of the Kilosa and Mvomero districts (Study areas). 


\subsection{Surveys and Interviews}

Key Informant Interviews to gather valuable evidence on conflict processes, causes and effects were used for characterizing natural resource use conflicts in Kilosa and Mvomero. In-depth interviews with local community members, ward and village leaders, district officials aided in constructing natural resource use conflict typology by focusing on parameters such as (i) the nature of the resources being contested for, (ii) the nature and type of natural resource use conflicts, (iii) the causes of conflicts, and (iv) the actors involved (Pegg, 2003). Longitudinal data and information were used to track historical changes of natural resource uses. A systematic time series evaluation of different conflict items, scenarios and impacts was carried out. By collecting comprehensive information on households, being sensitive to conflict intensity, and disaggregating by place, purposely designed focus group discussions and key informant interviews were used to uncover the unfolding process of conflict rather than assessing conflict as a one-off shock. Key informant interviews and focus group discussions also fostered the understanding of the consequences of violent conflicts on the lives, livelihoods and human capital of individuals and households.

2.3 Developing a natural resource use conflict severity index and a natural resource use conflict assessment and monitoring framework

A natural resource use conflict severity index was developed based on the conflict barometer framework of the Heidelberg Institute for International Conflict Research in order to create a customized framework (Table 1). The Heidelberg Institute for International
Conflict Research framework was modified through concerted data collection campaigns, key informant interviews, focus group discussions and consultative meetings with district officials, ward and village executive officers, and community members. A systematic time series evaluation of different conflict items, scenarios and impacts also helped to create a customized index and the natural resource use assessment and monitoring framework. A scale of 1 to 5 of the Heidelberg Institute for International Conflict Research framework was modified to produce a framework with a scale ranging from 0 to 4 , which was tested and then applied in quantifying the conflict severity and intensities in the study area, disaggregated at ward level (40 wards in Kilosa and 30 wards in Mvomero). On this new scale $0=$ No conflict, $1=$ Latent conflict, $2=$ Manifest conflict, $3=$ Crisis, $4=$ Severe Crisis.

\subsection{Mapping the distribution of natural resource use conflicts and} their intensities

Spatial interpolation of natural resource use conflicts was carried out using the method of Inverse Distance Weighting (IDW) in the Quantum GIS software. The IDW method was used to estimate the values of natural resource use conflict intensities at unsampled points using a linear combination of natural resource use conflict intensities at sampled villages weighted by an inverse function of the distance from the point of interest to the sampled areas. The assumption was that sampled areas closer to the unsampled ones are more similar to them in their values than those further away (Shepard, 1968). The simplest weighting function is inverse power, given as $w_{i}=1 / d_{i}^{p}$. However, the following equation was used to express the weights;

Table 1: A framework from the Heidelberg Institute for International Conflict Research for natural resource use conflict assessment

\begin{tabular}{|c|c|c|c|c|}
\hline $\begin{array}{l}\text { State of } \\
\text { violence }\end{array}$ & $\begin{array}{l}\text { Intensity } \\
\text { group }\end{array}$ & $\begin{array}{l}\text { Level of } \\
\text { intensity }\end{array}$ & $\begin{array}{l}\text { Name of } \\
\text { intensity }\end{array}$ & Description \\
\hline \multirow[t]{2}{*}{ Non-violent } & \multirow[t]{2}{*}{ Low } & 1 & $\begin{array}{l}\text { Latent } \\
\text { conflict }\end{array}$ & $\begin{array}{l}\text { A positional difference over definable values of national meaning is considered to } \\
\text { be a latent conflict if demands are articulated by one of the parties and perceived } \\
\text { by the other as such. }\end{array}$ \\
\hline & & 2 & $\begin{array}{l}\text { Manifest } \\
\text { conflict }\end{array}$ & $\begin{array}{l}\text { A manifest conflict includes the use of measures that are located in the stage } \\
\text { preliminary to violent force. This includes for example verbal pressure, threatening } \\
\text { explicitly with violence, or the imposition of economic sanctions. }\end{array}$ \\
\hline \multirow{3}{*}{ Violent } & Medium & 3 & Crisis & $\begin{array}{l}\text { A crisis is a tense situation in which at least one of the parties uses violent force in } \\
\text { sporadic incidents. }\end{array}$ \\
\hline & \multirow{2}{*}{ High } & 4 & $\begin{array}{l}\text { Severe } \\
\text { crisis }\end{array}$ & $\begin{array}{l}\text { A conflict is considered to be a severe crisis if violent force is used repeatedly in } \\
\text { an organized way. }\end{array}$ \\
\hline & & 5 & War & $\begin{array}{l}\text { A war is a violent conflict in which violent force is used with certain continuity in } \\
\text { an organized and systematic way. The conflict parties exercise extensive measu- } \\
\text { res, depending on the situation. The extent of destruction is massive and of long } \\
\text { duration. }\end{array}$ \\
\hline
\end{tabular}




$$
\lambda_{i}=\frac{\frac{1}{d_{i}^{p}}}{\sum_{i=1}^{n} \frac{1}{d_{i}^{p}}}
$$

Where, $\lambda_{i}$ is the value to be estimated, $d i . ., d n$ are distances from the $n$ data points to the estimated point $n$., and $n$ represents the number of sampled points used for the estimation, $p$ is power parameter. For the choice of value for $p$, the degree of smoothing desired in the interpolation, the density and distribution of samples being interpolated, and the maximum distance over which an individual sample is allowed to influence the surrounding ones were considered. These $p$ values were also chosen in order to clearly differentiate various natural resource use conflict intensities. The greater the values of $p$ assigned the greater the influence to values closest to the interpolated point. The main motivation for using IDW interpolation was to predict conflict intensity values at unsampled villages due to the difficulty of reaching all the villages in the two districts. Therefore, using the IDW approach it was possible to go beyond political boundaries and estimate conflict intensity. Moreover, the IDW method permitted the inclusion of more observations than only the nearest points which were reached through surveys. Furthermore, different natural resource use conflict intensities were represented in maps by varying the colors of each zone based on the conflict severity index. Moreover, climate data (rainfall and temperature) and land cover changes were analyzed to obtain information on the magnitude of changes in the study area, and get an idea of how these factors may be connected with the natural resource use conflicts in the study area. A hand-held Global Positioning System (GPS) device was used to collect spatial points of all the wards in the two districts.

\section{Results and Discussion}

\subsection{Characterization of Natural Resource Use Conflicts}

In this study, four types of natural resource use conflicts were identified in Kilosa and Mvomero, which are human-wildlife, local transboundary conflicts involving neighboring villages, conflicts involving communities against investors and lastly, conflicts involving farmers and livestock keepers. The latter (farmers-livestock keepers) is reportedly and oddly the most prominent and deadliest in the study areas (Figure 2). The resources which are contested include land, water, pasture, minerals and crops whereby crop raiding by livestock has been a cause of repeated and deadly clashes in the conflict-prone areas of the two districts. This does not only happen because crops are being damaged but trampling of agricultural lands by animals causes land degradation, which unwittingly reduces soil fertility by causing soil hardening on one hand and exposing the soil to wind and water erosion on the other. Soil hardening reduces water infiltration, and thus lowers crop soil water holding capacity by reducing infiltration.

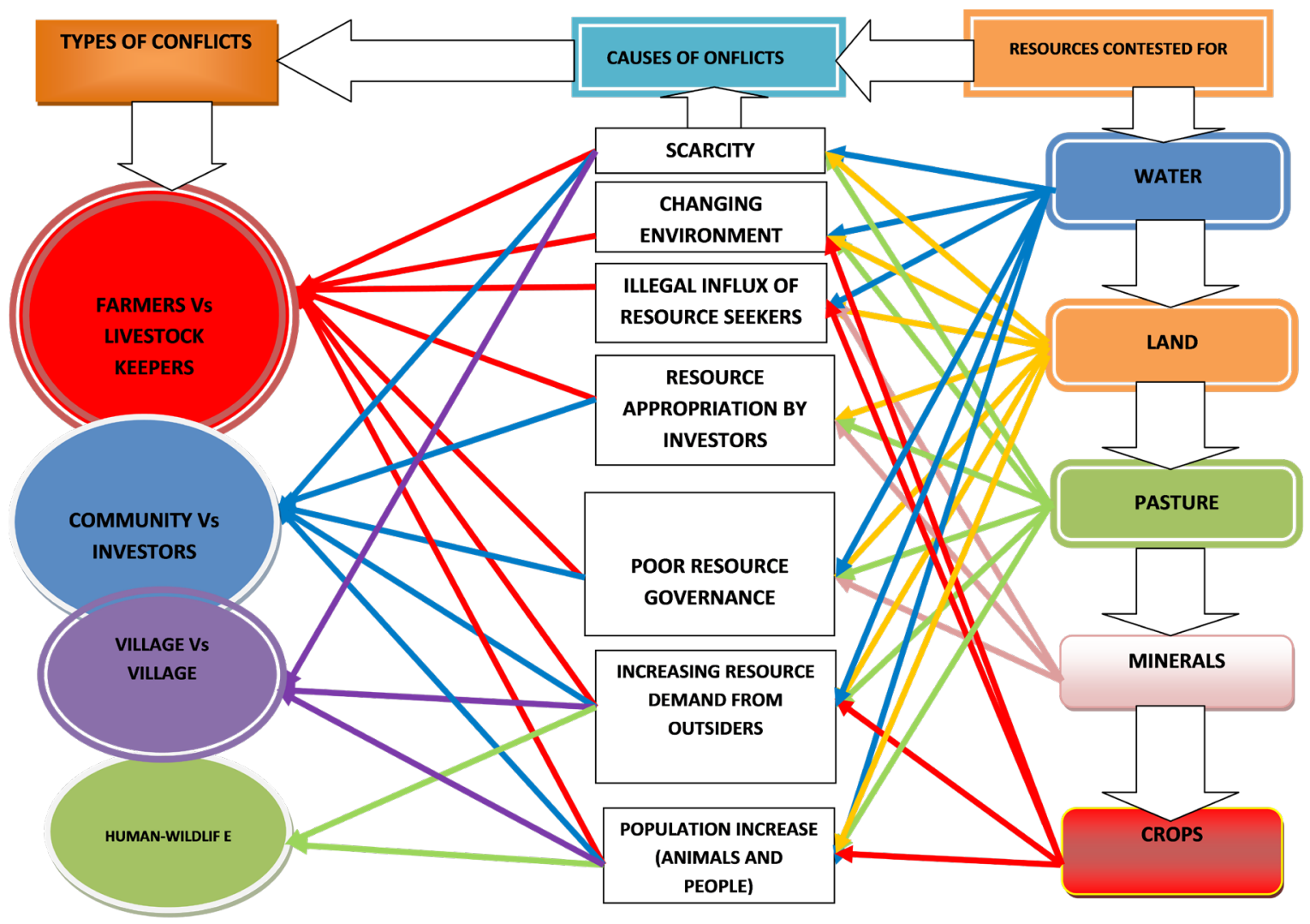

Figure 2: Natural resource use conflict typology. 
In addition to this, clashes between farmers and livestock keepers have been reported during the end of cropping seasons in some areas due to the scramble for crop residues, where farmers tend to burn the residues to avoid incursion by livestock in search for pasture. Feeding on crop residues has been said to equally reduce soil fertility because of nutrient mining as once crop residues are removed, the nutrients contained in them will no longer be recycled into the agricultural lands again. This depletes soil nutrients and is another form of soil degradation and, meaning that it is in a way costly to farmers. With continued awareness-raising by agricultural extension officers in Kilosa and Mvomero, farmers in the areas are well aware of the effects of trampling and nutrient mining on crop productivity. That is why, despite severe clashes between farmers and livestock keepers being common during the dry season, clashes are also happening at the end of the cropping season. Figure 2 shows the conflict typology, encompassing the types of resources that are contested, actors involved in the conflict, the conflict types, and the causes of the conflicts, both natural and anthropogenic.

Another reported cause of farmer-livestock keeper conflict is the changing environment (land use changes and climate change and variability). Nevertheless, land use and land cover change analysis defeat the general perception that the rampant natural resource use conflicts in Kilosa and Mvomero are a result of encroachment by livestock keepers into the croplands and other agricultural areas occupied by farmers. Figure 3 shows how land has been converted into agricultural land in a space of 20 years (i.e. 1995-2016), clearing forests and encroaching into areas which were once grazing lands (Figure 3 and Table 2). Land use changes in connection with the conflicts in Kilosa and Mvomero are fully supported by Benjaminsen, Maganga and Abdallah (2009), who contended that attempts to expand and modernize agriculture and the government's quest to confine livestock keeping to pastoral villages (Kambala and Mela in Mvomero; Kiduhi, Mabwegere, Twatwatwa, Kwambe in Kilosa) have reduced access to wetlands by pastoralists. This is said to have created an anti-pastoral environment in Kilosa and Mvomero. Reportedly, the designated pastoral villages lack sufficient pastures and water supplies, leading herders to search for water and pasture elsewhere and thus causing frequent crop raiding. Consequently, the main and likely only strategy at the disposal of pastoralists to thwart this unfriendly trend is by bribing officials (Benjaminsen, Maganga \& Abdallah, 2009). As a result, corruption has seriously undermined farmers' trust in authorities and this has led actors to try to solve natural resource use conflicts through other means, notably violence. This is well explained by the rebel greed mechanism and the grievance mechanism premises, which is explained in detail in the following sub-sections.

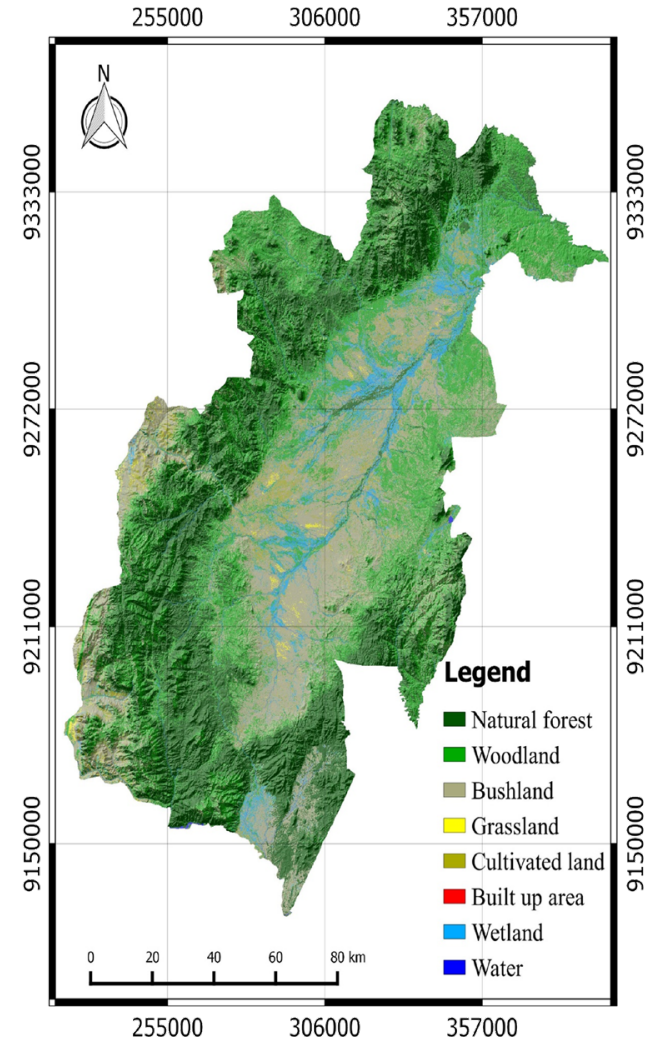

(a)

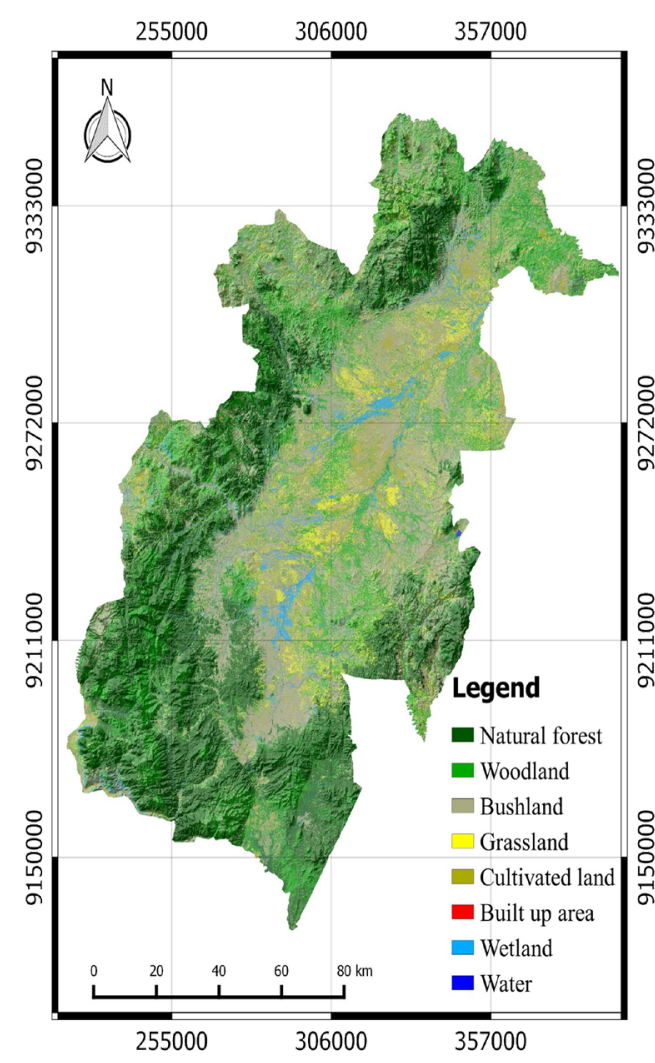

(b)

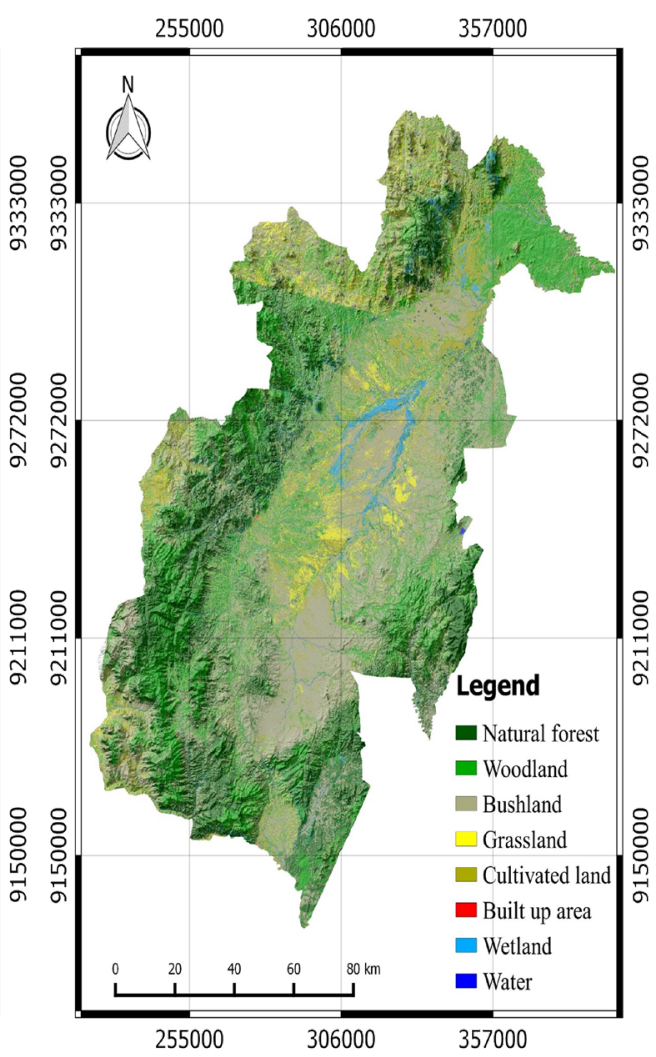

(c)

Figure 3: Land use/cover change analysis for Kilosa and Mvomero [1995(a), 2006(b) and 2016(c)]: (Authors' analysis, 2017). 
Table 2: Land use/cover area distribution between 1995 and 2016

\begin{tabular}{|l|c|c|c|c|c|c|}
\hline \multirow{2}{*}{ Land Cover } & \multicolumn{2}{|c|}{1995} & \multicolumn{2}{c|}{2006} & \multicolumn{2}{c|}{ (ha) } \\
\cline { 2 - 7 } Natural forest & 586890 & 31.89 & 482930 & 26.24 & 360070 & 19.56 \\
\hline Woodland & 581630 & 31.6 & 531975 & 28.90 & 472915 & 25.69 \\
\hline Bushland & 489250 & 26.58 & 547450 & 29.74 & 679380 & 36.91 \\
\hline Grassland & 7215 & 0.39 & 136614 & 7.42 & 85730 & 4.66 \\
\hline Cultivated land & 80840 & 4.39 & 90858 & 4.94 & 203253 & 11.04 \\
\hline Built-up area & 250 & 0.01 & 370 & 0.02 & 2039 & 0.11 \\
\hline Wetland & 93530 & 5.08 & 50118 & 2.72 & 36833 & 2.00 \\
\hline Water & 1015 & 0.06 & 305 & 0.02 & 400 & 1840620 \\
\hline Total & 1840620 & 100 & 1840620 & 100 & 100 \\
\hline
\end{tabular}

In line with land use changes, climate change and variability (decreasing rainfall) has also been claimed to lead to water scarcity in the conflict-prone areas and is thus a critical cause of natural resource use conflicts in the areas and probably beyond. Climate data (rainfall) analysis from 1979 to 2014 showed that, over the years, there has not been a discernible rainfall decrease but a slight increase in annual total rainfall for Mvomero (Figure 4). Nevertheless, a few patches of above and below normal rainfall spells have been observed. This implies that climate change is not the main cause or is not a cause at all of the conflicts in Kilosa and Mvomero. What has been deduced through a series of key informant interviews is that seasonal water and pasture scarcity play a major role in causing natural resource use conflicts in Mvomero and Kilosa, and this happens during dry periods (around October to February) and once the wet season begins reported cases of conflicts even in the most notorious areas plummet significantly. Apparently, uneven rainfall distribution, seasonal and inter-annual variations (early withdrawal of rainfall seasons and unpredictable late onset of dry seasons are the relevant factors rather than climate change.

Nevertheless, the natural resource use conflicts in Kilosa and Mvomero are premised on the governance institutions regulating resources exploitation, land ownership, and access to the areas for those coming from outside the districts. As for the conflicts involving investors against communities, typical of the Magomeni ward in Kilosa and other sporadic areas in Mvomero, there seems to be land grabbing by the so-called investors (resource governance issue), and the stakeholders' theory is used to back up the scenario. The theory calls for specific roles by investors in justifying their existence and a sense of operational responsibility in host communities with the aim of enhancing socio-economic development (Freeman, Wicks \&
Parmar, 2004). Moreover, as argued by Freeman, Wicks and Parmar (2004), the stakeholders' theory is pro-shareholder, in the sense that it recognizes obligations that investors need to execute in the interest of the local people. This implies that advocates of the stakeholders' theory believe that investors not only manage its employees but also members of the community where they operate. However, things are different in the conflict-prone areas, where investors would do whatever it takes to protect their properties with little regard of the welfare of the people in the communities where they operate. This is reportedly and possibly one of the major causes of conflict outbreaks in the study areas.

Furthermore, the study revealed that there is a huge tension between resources that are demanded by both parties and what is available to honor those demands. Over the years, the number of animals and people has been on the increase, and thus the demand for grazing land, water points and agricultural land has been on the increase too. While it is obvious that land is a fixed resource, with a multitude of uses and users, the increase in animal and human population has exerted even more unparalleled pressure due to scrambling for the same fixed resource (land), which ought to accommodate different types of users, with their varying degrees of uses. Land use land cover change analysis also revealed an increase in the built-up up area from $0.01 \%$ in 1995 to $0.11 \%$ in 2016 , while the forest cover has been plummeting from $32 \%$ in 1995 to $20 \%$ in 2016 (Table 2 and Figure 3). This justifies the aforesaid claim on population increase, thus creating more pressure on land, eventually causing an ever-increasing land scarcity. Arguably, population increase leads to increasing pressure on land that results into land degradation and land conflicts between land users (Lambin \& Meyfroidt, 2011). 


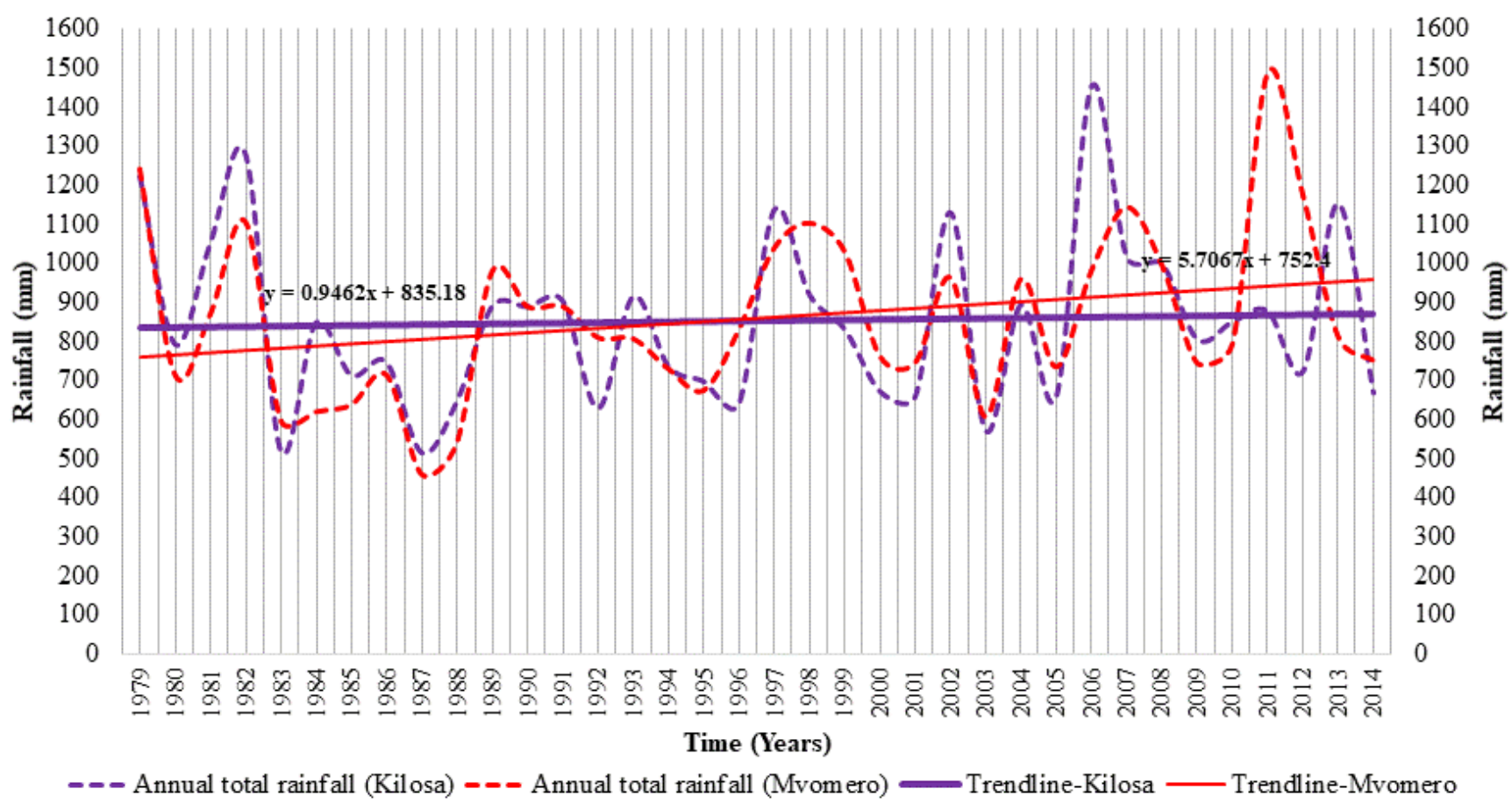

Figure 4: Rainfall analysis for Mvomero and Kilosa (Authors' Analysis, 2017).

In line with land scarcity due to the increase in livestock population, water has increasingly been scarce too, thus users have been competing for this ever-dwindling resource. In addition, the Economic Commission for Africa (2012) categorized the factors behind natural resource use conflicts as demographic (e.g. increase in human and animal population), natural (e.g. drought and climate change), anthropogenic (e.g. natural resources degradation) conservational (e.g. reservation of land for protected areas), knowledge-related (e.g. vague understanding in existing laws on rights of access to land and other natural resources), governance-oriented (e.g. rent seeking, corruption, and misuse of power), and economic (e.g. competition over natural resources such as timber, minerals, land for large investments, and water for irrigation versus other uses). Most of the factors reported by the Economic Commission for Africa (2012) are also supported by the findings of this study.

As stated earlier, the most prominent natural resource use conflict in the study area is between farmers and livestock-keepers. As suggested by Zoomers (2010), it is reiterated in this paper that the root of the conflicts between farmers and livestock-keepers in Mvomero and Kilosa is inadequate security on land that rural people subsist on, since access to land and water resources is crucial for rural peoples' livelihoods, both farmers and livestock keepers. Contrary to what has been reported by Banks (2008), that most resource conflicts in Papua New Guinea were actually better conceived as conflicts around identity and social relationships and not actually conflicts over natural resource use, natural resource use conflicts in Kilosa and Mvomero are centered around livelihood improvements, as expressed by Kajembe, Mbwilo, Kidunda and Nduwamungu (2009), and their dimensions, levels and intensities vary considerably from one place to the other, depending on the type of resource which contested, the actors involved, types of institutions resolving the conflicts and specific causes. It therefore suffices to say that, water, crops, pasture and minerals are the main natural resources behind the conflicts, and as suggested by Maphosa (2012), the aforementioned resources have to be treated as crucial dimensions of conflict prevention and resolution in Kilosa and Mvomero.

The study also revealed that farmer-livestock keeper conflicts in Kilosa and Mvomero are supported by both the rebel greed mechanism and the grievance mechanism premises. The rebel greed mechanism is premised on local groups engaging in quasicriminal activity in order to benefit from natural resources, while the grievance mechanism is based on grievances over the negative impact of resource appropriation on local people. Referring to the conflicts between farmers and livestock-keepers, blood-shedding clashes are constantly reported to occur on several occasions, involving organized local groups from both sides who are armed and intentionally seeking to appropriate pasture for their livestock, especially during the dry season. This has resulted in several revenge actions by farmers (grievance mechanism) following the negative impact of crop raiding by livestock keepers. Moreover, as for the feelings of ethnic marginalization, both farmers and livestock keepers expressed this as a serious concern which needs concerted attention from the government, as suggested elsewhere by Collier and Hoeffler (2004). 
Furthermore, Banks (2008) maintains that weak and often corrupt governance systems, inappropriate economic policies and management practices, including inadequate land-use plans have all fermented natural resource use conflicts in various places around the world. This argument seems to be in line with what is happening in the two districts with regard to natural resource use conflicts, which have resulted in the loss of lives and properties, creating a state of insecurity, low productivity leading to accelerated food insecurity, the generation of a landless class, increased poverty, rapid environmental degradation and the rendering of children unable to go to school in some areas.

The impact of natural resources on conflicts in the area can indeed be attributed to governance, while also depending on the strength of the institutions which are vested with powers to intervene whenever a conflict breaks out, as suggested by Humphreys (2005). It has also been revealed that in some areas, natural resource use conflicts are a means through which local social activities are articulated. Richards (2001) suggested that in order to better understand natural resource use conflicts, one has to understand the nature of socio-cultural activities in the area.

\subsection{A natural resource use conflict severity index and conflict assessment and monitoring framework}

As discussed earlier, the causes for all natural resource use conflicts are overlapping and dynamic, thus frequent monitoring is imperative to establish specific causes for a specific conflict in a specific period of time. As a result, the conflict intensity and severity index framework from the Heidelberg Institute for International Conflict Research was modified and adapted to come up with a customized natural resource use conflict severity index. This enabled the development and testing of a natural resource use conflict monitoring and assessment framework (Table 3 ). This follows a concern showed by Hamilton (2011), Humphreys (2005) that most natural resource conflict resolution research frameworks appear to be highly inept, with a lack of succinct indicators that can be used to differentiate intensity levels from one place to another as is the case with the Heidelberg Institute for International Conflict Research framework (Table 1). Unlike the Heidelberg Institute for International Conflict Research framework, which does not have indicators and starts with a latent conflict (Level 1) and goes all the way to the war (Level 5), the adapted framework reorganizes the five intensity levels as 0 , 1, 2, 3, 4 instead, with intensity level 5 (War) being removed as in Tanzania the powers and discretion to declare a war is vested on the President, who is the Commander in Chief. Therefore, one level back namely No conflict ( 0 ) was added into the modified framework. The customized natural resource use conflict assessment and monitoring framework has a list of indicators for each conflict intensity group/ level which helps in not only monitoring the unfolding process of a conflict, but also monitoring the effectiveness of various conflict management interventions. Therefore, the customized framework consists of the indicators, natural resource use conflict severity index, the description of the conflict process, and the name of the natural resource use conflict intensity (Table 3).

\subsection{Mapping of natural resource use conflicts in Kilosa and Mvomero}

Mapping natural resource use conflicts in Kilosa and Mvomero provided a bird's eye view of the spatial distribution of the problem. Areas with high-level crises (Intensity level 4) were depicted, and areas with very low and without conflicts have also been identified as shown in Figure 5 to Figure 10. One of the primary objectives of carrying out natural resource use conflict mapping is to enable planning and prioritization of conflict resolution strategies according to their severity and potential and existing impacts on community livelihoods.

The study found that the most prominent feature was a respect for district boundaries, where conflicts of different intensities have been observed in neighboring wards of different districts (Mbigiri in Kilosa and Dakawa in Mvomero are the cases in point here). In Figure 5, the map clearly indicates that moving from lowland to upland, the conflict intensity decreases. The causes of conflicts vary from one place to another although the intensities are the same.

For example, the causes of conflicts in the Mkindo ward are different from those in Doma, and the causes of severe crisis in Tindiga are different from those causing severe crisis in Ruhembe (Figure 8 to Figure 10). This highlights the importance of having different actors (sectors) in conflict resolution/management. In Doma for example besides farmers and pastoralists, you have wildlife as an agent that stirs and enhances conflict intensity between farmers and pastoralists (Figure 5 to Figure 7).

Another prominent characteristic is that highland areas in Mvomero are free of natural resource use conflicts while flat lands and plains are seriously prone to natural resource use conflicts, specifically farmer-livestock keeper conflicts. In Mvomero, severe conflicts have also been identified through mapping and are spatially distributed from the northern areas (Kanga and Mziha), the central area (Sungaji, Mkindo and Hembeti) and in the south (Doma and Lubungo). More often than not, deadly clashes happen in the central wards of Mkindo, Hembeti and Sungaji where lives and properties are constantly lost, year in year out (Figure 5 to Figure 7).

The study also found that the eastern part of Kilosa is seriously affected by farmer-livestock keeper conflicts, with some patches in the central part of the district, while in the south, the Ruhembe ward also suffers from a severe conflict, which is more of a communityinvestor crisis involving land grabbing (Figure 8 to Figure 10). In all these scenarios, the extent of destruction of property and life is massive, far more than other socio-economic impacts, including abandonment of production activities in the areas. A different conflict appears in the central part of Kilosa, involving an investor, where local community members are claiming alienation through inadvertent land grabbing. Other conflict types range from a latent state to crisis, which also require the attention of authorities to prevent them from maturing into deadly conflicts. 
Table 3: A natural Resource Use Conflict Monitoring and Assessment Framework (Adapted from the Heidelberg Institute for International Conflict Research)

\begin{tabular}{|c|c|c|c|}
\hline $\begin{array}{l}\text { Name of Natural } \\
\text { Resource Use } \\
\text { Conflict Intensity }\end{array}$ & Description & Indicators & $\begin{array}{l}\text { Natural Resource } \\
\text { Use Conflict } \\
\text { Severity Index }\end{array}$ \\
\hline No conflict & $\begin{array}{l}\text { No discernible positional differences over the } \\
\text { use of and/or access to natural resources. }\end{array}$ & $\begin{array}{l}\text { 1. Existence and practicing of rules for the use of natural } \\
\text { resources } \\
\text { 2. Properly defined resource tenure } \\
\text { 3. No reported or pending cases on either potential or exis- } \\
\text { ting misunderstanding/disagreement/clashes regarding the } \\
\text { use of or access to natural resources } \\
\text { 4. Very good to excellent co-operation between different } \\
\text { community groups on social matters } \\
\text { 5. No differences between the aspirations of community and } \\
\text { expectations of investors regarding resource extractions }\end{array}$ & 0 \\
\hline Latent conflict & $\begin{array}{l}\text { A positional difference over definable values } \\
\text { is considered to be a latent conflict if de- } \\
\text { mands are articulated by one of the parties } \\
\text { and perceived otherwise by the other parties. } \\
\text { Discord/disagreement arising within a group } \\
\text { or between groups when the beliefs or ac- } \\
\text { tions of one or more members of the group } \\
\text { are either resisted by or unacceptable to one } \\
\text { or more members of another group. This is } \\
\text { usually a non-violent situation. }\end{array}$ & $\begin{array}{l}\text { 1. Misunderstanding between groups regarding the use of a } \\
\text { resource } \\
\text { 2. Contradictory natural resource needs and values } \\
\text { 3. Cultural misconceptions between community groups and } \\
\text { outsiders } \\
\text { 4. Differences between the aspirations of community groups } \\
\text { and expectations of NGOs or commercial companies/inves- } \\
\text { tors; } \\
\text { 5. Lack of co-operation between different community groups; }\end{array}$ & 1 \\
\hline Manifest conflict & $\begin{array}{l}\text { A manifest conflict includes the use of } \\
\text { measures that are located in the stage } \\
\text { preliminary to violent force. This includes } \\
\text { for example verbal pressure, threatening } \\
\text { explicitly with violence, or the imposition of } \\
\text { economic sanctions. This is equally a non- } \\
\text { violent situation }\end{array}$ & $\begin{array}{l}\text { 1. Verbal exchanges } \\
\text { 2. Existence of threats amongst various resource users } \\
\text { 3. Social Sanctions and scolding } \\
\text { 4. Disputes over resource boundaries between individuals or } \\
\text { 5roups }\end{array}$ & 2 \\
\hline Crisis & $\begin{array}{l}\text { A crisis is a tense situation in which at least } \\
\text { one of the parties uses violent force in spora- } \\
\text { dic incidents. }\end{array}$ & $\begin{array}{l}\text { 1. Violent force used irregularly } \\
\text { 2. Extent of destruction of property and life is moderate } \\
\text { 3. Temporary abandonment of resource-use activities } \\
\text { 4. Availability of court cases }\end{array}$ & 3 \\
\hline Severe crisis & $\begin{array}{l}\text { A conflict is considered to be a severe crisis } \\
\text { if violent force is used repeatedly in an orga- } \\
\text { nized way. } \\
\text { A violent conflict in which violent force is } \\
\text { used with certain continuity in an organi- } \\
\text { zed and systematic way. The conflict parties } \\
\text { exercise extensive measures, depending on } \\
\text { the situation. } \\
\text { The extent of destruction is massive and of } \\
\text { long duration. }\end{array}$ & $\begin{array}{l}\text { 1. Violent force occurs repeatedly and is well organized } \\
\text { 2. Violent force used in a systematic way } \\
\text { 3. Extensive measures are deployed by the parties involved } \\
\text { 4. Extent of destruction of property and life is massive } \\
\text { 5. Migration to other areas in search of relief and security } \\
\text { 6. Permanent abandonment of resource-use activities }\end{array}$ & 4 \\
\hline
\end{tabular}




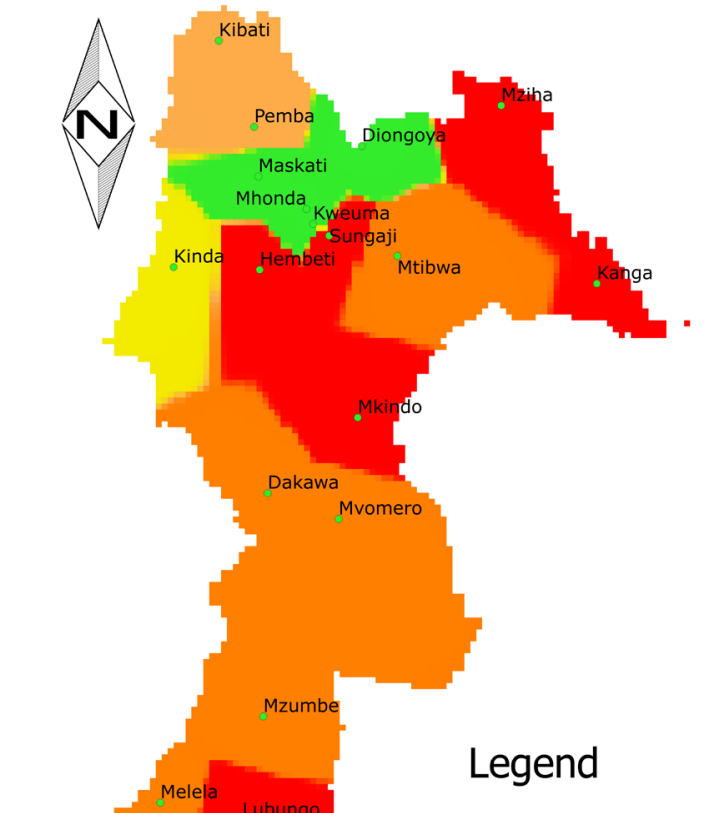

Resource Use Conflict Intensity_Mvomero

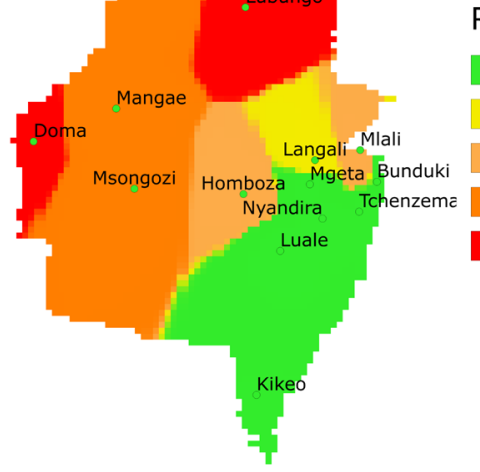

0 : No Conflict

1: Latent Conflict

2: Manifest Conflict

3: Crisis Conflict

4: Severe Crisis Conflict

0

$25 \quad 50$

75

$100 \mathrm{~km}$

Figure 5: Spatial distribution of natural resource use conflicts by wards in the Mvomero district. 


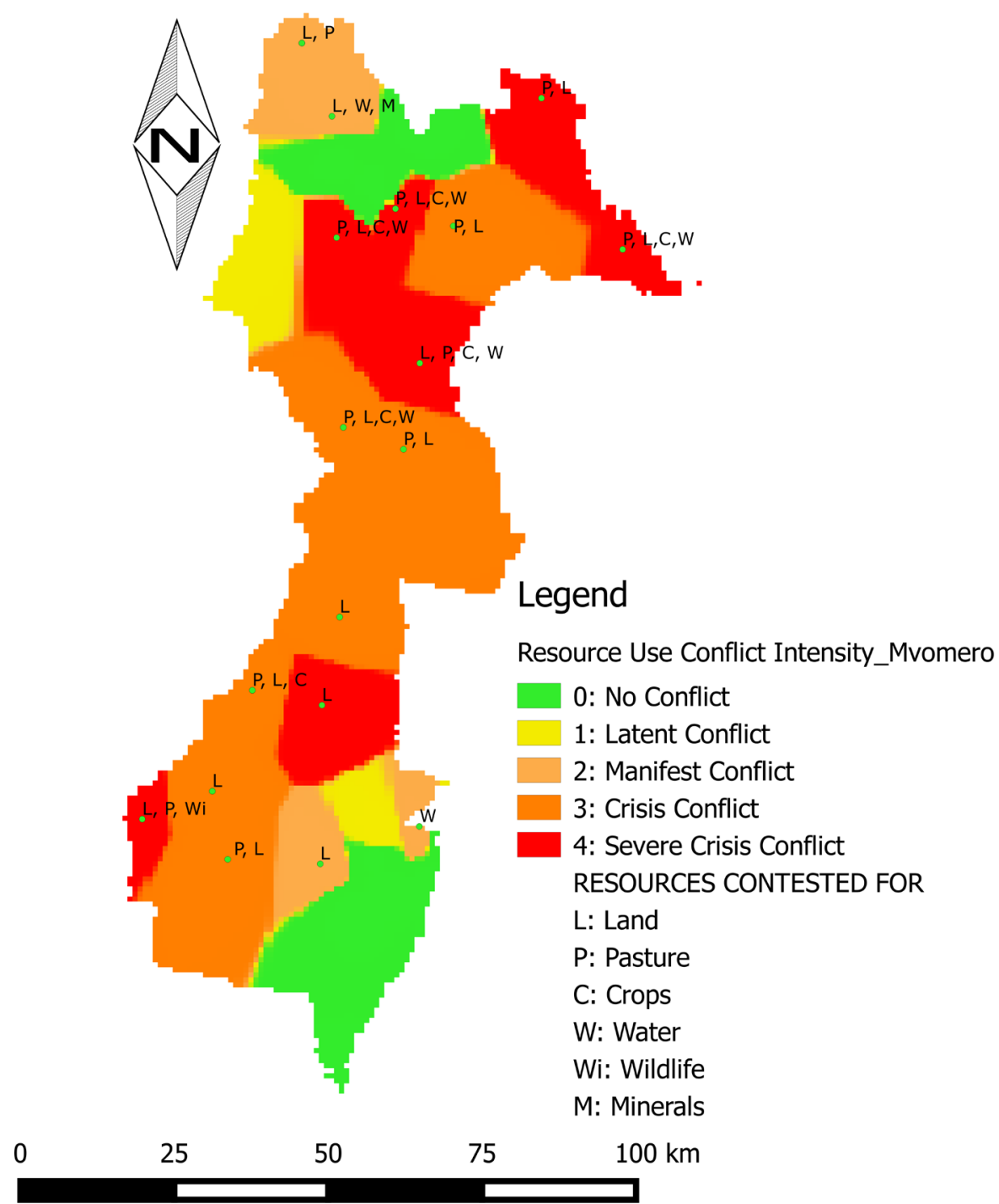

Figure 6: Spatial distribution of natural resources which are contested for in the Mvomero district. 


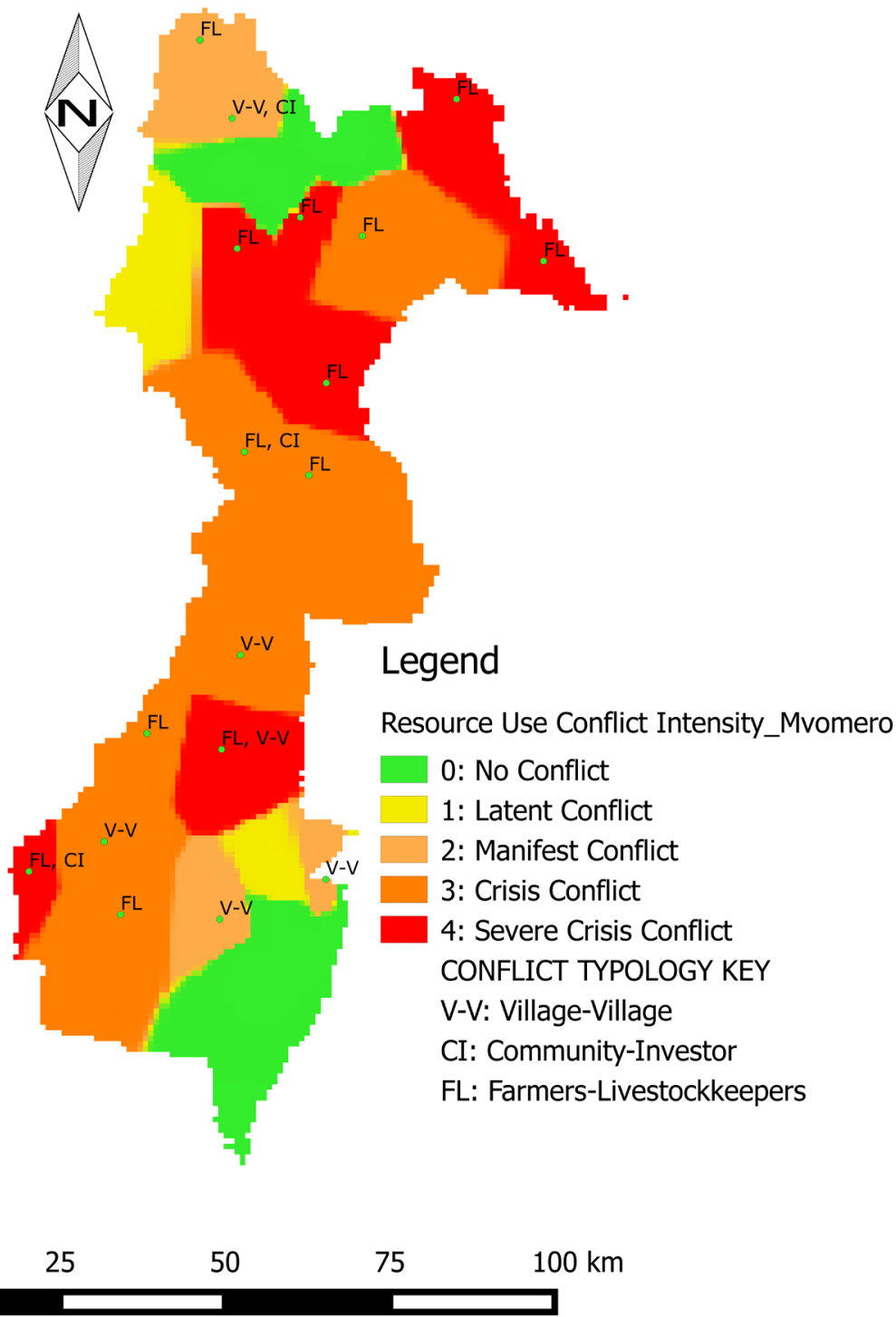

Figure 7: Spatial distribution of natural resource use conflict types in the Mvomero district. 


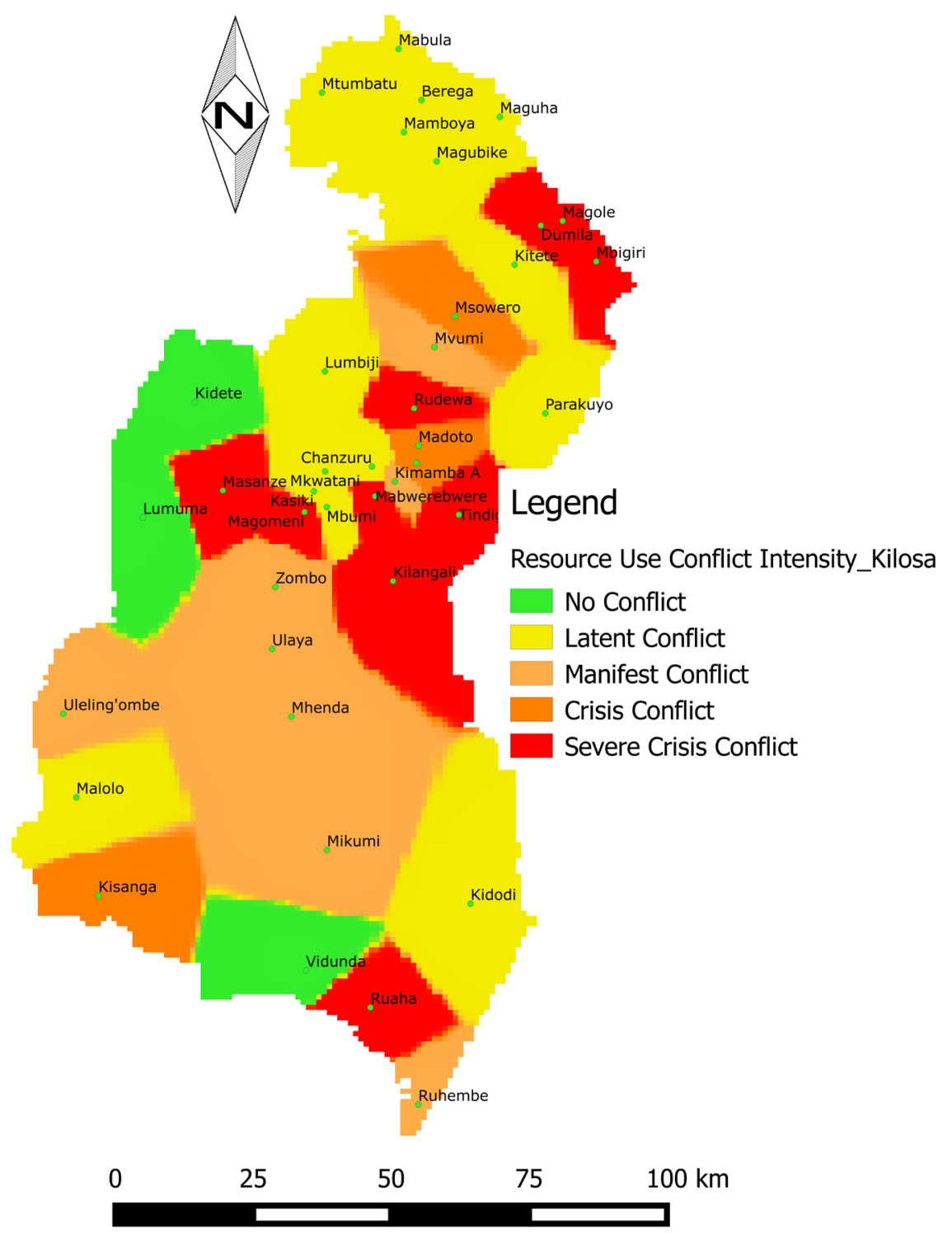

Figure 8: Spatial distribution of natural resource use conflicts by wards in the Kilosa district. 


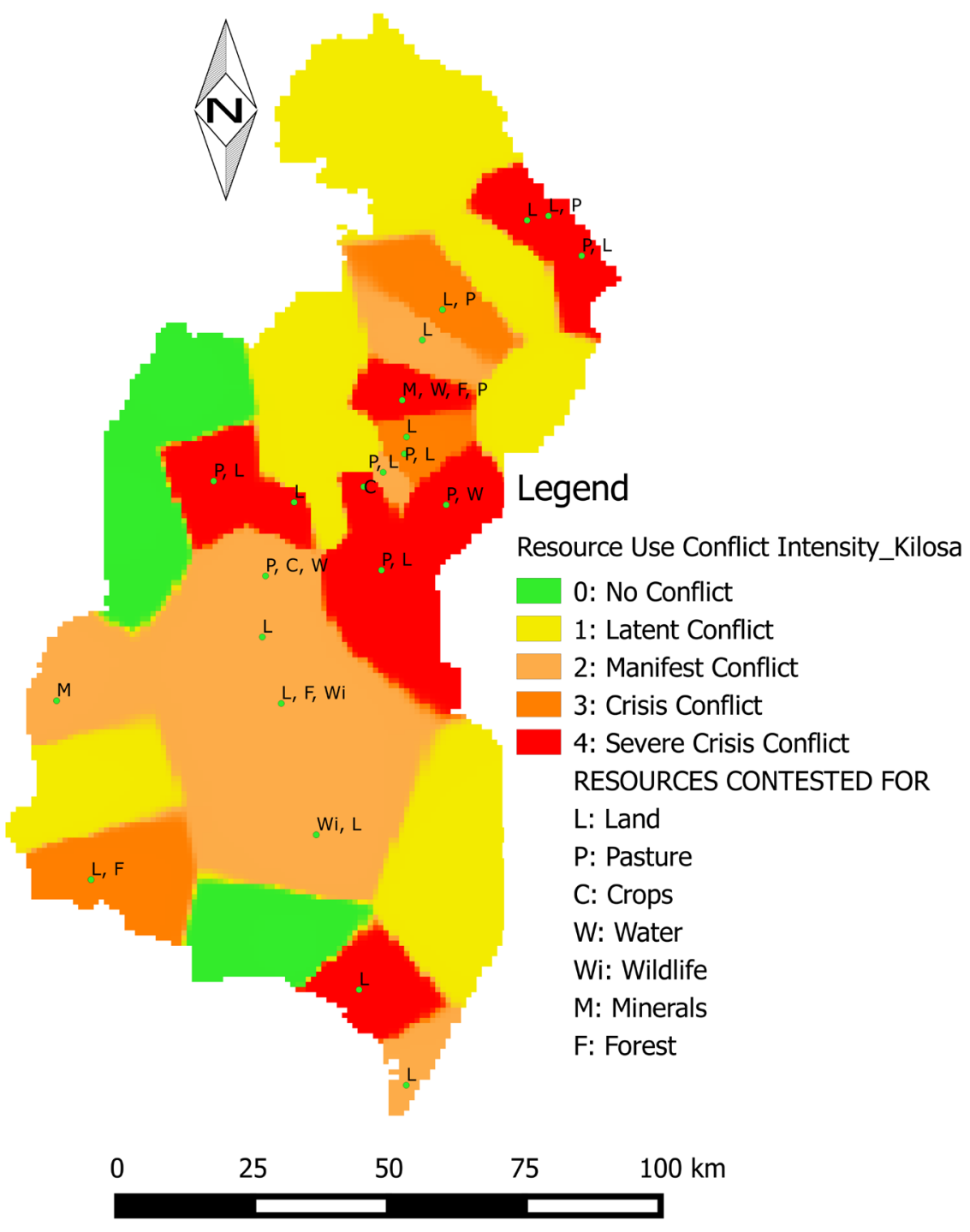

Figure 9: Spatial distribution of natural resources which are contested for in the Kilosa district. 


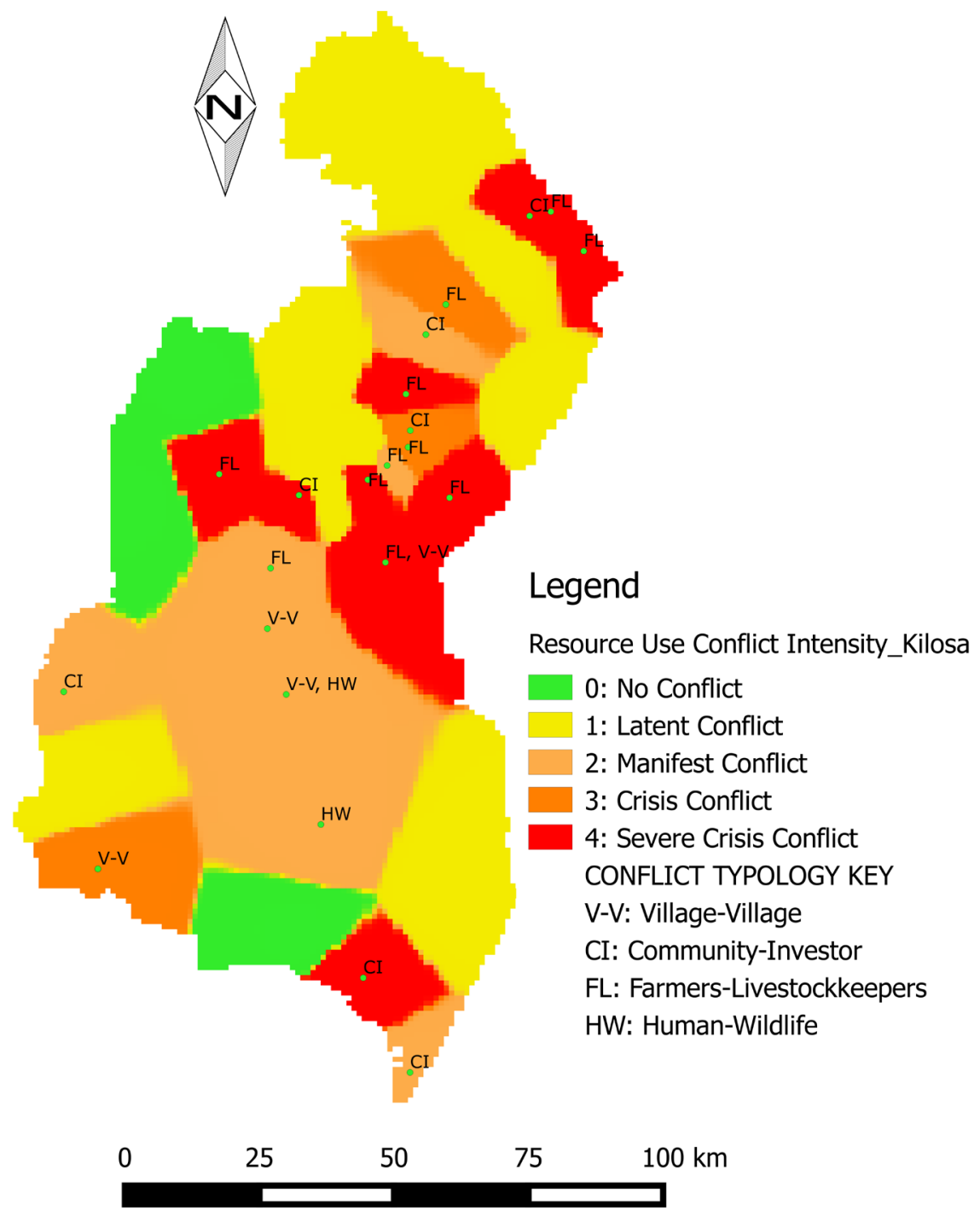

Figure 10: Spatial distribution of natural resource use conflict types in the Kilosa district. 


\section{Conclusions and Recommendations}

\subsection{Conclusions}

Generally, the conflicts in Kilosa and Mvomero are livelihoodbased conflicts and not conflicts of maintaining a social identity, and therefore strategies towards managing the conflicts should keenly take that into consideration. However, there is overlap of causes of conflicts among conflicting actors' categories and among the natural resources contested, thus making natural resource use conflict a complex phenomenon. Colloquially, most of the causes of conflicts are cutting across sectors and natural resources as well. This implies that, crosscutting and integrated mechanisms are also needed to address natural resource use conflicts, with the hope that those integrated mechanisms will learn from and complement one another thus creating a synergy in natural resource use conflict resolution. Moreover, several factors are attributed to the causes of the conflicts, but governance is said to be a key contributing factor since most of the other causes are secondary to it. Furthermore, the developed framework has helped in assessing the conflict situations and differentiating the actors involved in the natural resources which are contested, the severity of the conflict situation and the types of conflicts. Much as the primary objective of mapping natural resource use conflicts was to help in prioritization of conflict resolution based on financial and human resourcesavailability, there is a clear connotation of efforts stakeholders at different decision-making levels have to undertake to distribute conflict resolution strategies. This is because all levels of conflict intensity are not static and are not exclusive, such that what we see as latent conflict today has a possibility of becoming a crisis in the future. In addition, there is the potential of reducing conflict at one level while at the same time increasing it at another level. As such, a balance needs to be struck from both ends of the conflict severity typology and conflict management approaches have to be holistic.

\subsection{Recommendations}

(a) Owing to the complex nature of the conflict situations and overlapping of causes and conflict types, natural resource use conflict monitoring and management should be a continuous process regardless of the season because some parts of the districts are natural resource-endowed (water, pasture, fertile land for agriculture, minerals etc.), and therefore as long as the number of animals continues to increase, and the population growing at an alarming rate, there will always be tension between various resource-seeking groups, the end of which is a natural resource use conflict. Furthermore, constant assessment and monitoring is equally imperative in order to evaluate the effectiveness of the deployed conflict management strategies since conflict intensities are not static.

(b) It is recommended to test and validate the developed conflict assessment and monitoring framework in other conflict prone areas in Tanzania in order to test its efficacy, usefulness and acceptability before it is published for wider use. (c) The natural resource use conflict typology and maps will make a lot more sense when disaggregated at village level. It is therefore recommended that similar studies be carried out at the village level to obtain more disaggregated results.

(d) It is high time to combine the approach used in this study with crowd sourcing and mapping approaches which would involve an interdisciplinary perspective in contemporary conflict tracking and management using modern Information and Communication Technologies. To that effect therefore, there is a dire need to upscale the study to include all the conflict-prone districts in Tanzania.

\section{Acknowledgments}

The authors wish to acknowledge the support of the Building Stronger Universities (BSU) II Programme through the Agroecology thematic area of Sokoine University of Agriculture for funding this pilot project. We are also highly thankful to the Kilosa and Mvomero district officials, more specifically the Land and Natural Resources Departments for giving us requisite support, both in the office and in the field. The information provided by villagers, village and ward executive officers in the conflict prone areas is also highly acknowledged as it formed the basis for characterizing and mapping of the natural resource-use conflict causes, intensities and effects in the two districts.

\section{References}

Banks, G. (2008). Understanding resource conflicts in Papua New Guinea. Asia Pacific Viewpoint, 49(1), 23-34. https://doi.org/10.1111/j.1467-8373.2008.00358.x

Benjaminsen, T. A., \& Bryceson, I. (2012). Conservation, green/blue grabbing and accumulation by dispossession in Tanzania. The Journal of Peasant Studies, 39(2), 335355. https://doi.org/10.1080/03066150.2012.667405

Benjaminsen, T. A., Maganga F. P., \& Abdallah, J. M. (2009). The Kilosa killings: Political ecology of a farmer-herder conflict in Tanzania. Development and Change, 40(3), 423445. https://doi.org/10.1111/j.1467-7660.2009.01558.x

Collier P., \& Hoeffler, A. (2004). Greed and grievance in civil war. Oxford Economic Papers, 56(4), 563-595. https://doi.org/10.1093/oep/gpf064

Economic Commission for Africa. (2012). Natural resources and conflict management: The case of land. Economic Commission for Africa in collaboration with Land Policy Initiative (LPI), Addis Ababa, Ethiopia.

Emanuel, M., \& Ndimbwa, T. (2013). Traditional mechanisms of resolving conflicts over land resource: A case of Gorowa community in northern Tanzania. International Journal of Academic Research in Business and Social Sciences, 3(11). https://doi.org/10.6007/ ijarbss/v3-i11/334

Freeman, R. E., Wicks A. C., \& Parmar, B. P. (2004). Stakeholder theory and the corporate objective revisited. Organization Science, 15(3), 364-369. https://doi.org/10.1287/ orsc. 1040.0066

Hamilton, D. I. (2011). Oil and gas companies and community crises in the Niger Delta. American Review of Political Economy, 9(1).

Humphreys, M. (2005). Natural resources, conflict, and conflict resolution: Uncovering the mechanisms. Journal of Conflict Resolution, 49(4), 508-537. 
https://doi.org/10.1177/0022002705277545

Kajembe, G. C., Mbwilo, A. J., Kidunda, R. S., \& Nduwamungu, J. (2009). Resource use conflicts in Usangu plains, Mbarali district, Tanzania. International Journal of Sustainable Development \& World Ecology, 10(4), 333-343. https://doi. org/10.1080/13504500309470109

Kajembe, G. C., Silayo, D. S. A., Mwakalobo A. B. S., \& Mutabazi, K. (2013). The Kilosa District REDD+ pilot project, Tanzania. A socioeconomic baseline survey. International Institute for Environment and Development (IIED), London.

Kideghesho, J. R. (2006). Wildlife conservation and local land use conflicts in Western Serengeti, Tanzania. Ph.D. dissertation, Norwegian Univ. of Sci. and Technology, Trondheim, Norway.

King, N. A. S. (2013). Conflict management among the farmers and pastoralists in Tanzania. International SAMANM Journal of Business and Social Sciences, 1(2), 40-50.

Krummenacher, H. (2008). Environmental factors as triggers for violent conflict: Empirical evidence from the 'FAST' Data Base. In L. Wirkus and R. Vollmer (Eds.), Monitoring Environment and Security, Brief 37. Bonn International Center for Conversion (pp. 4345). Bonn, Germany.

Lambin E. F., \& Meyfroidt, P. (2011). Global land use change, economic globalization, and the looming land scarcity. Proceedings of the National Academy of Sciences of the United States of America, 108(9), 3465-3472. https://doi.org/10.1073/ pnas. 1100480108

Maganga, F., \& Odgaard, R. (2007). Contested identities and resource conflicts in Morogoro Region, Tanzania: who is indigenous?. In Derman, Bill, Odgaard, Rie \& Sjaastad, Espen (Eds.), Conflicts over Land and Water in Africa. Oxford: Oxford University Press.

Maphosa, S. B. (2012). Natural resources and conflict: Unlocking the economic dimension of peace-building in Africa. Africa Institute of South Africa, AISA Policy Brief, 74

Massoi, L. (2015). Land conflicts and the livelihood of pastoral Maasai women in Kilosa district of Morogoro, Tanzania. Afrika focus, 28(2), 107-120. https://doi.org/10.13140/ RG.2.1.2904.6808

Matthew, R. (2008). Resource scarcity: Responding to the security challenge. New York:
International Peace Institute.

Mbonde, J. F. (2015). Assessment of land use conflicts in Tanzania: A case study of Songambele and Mkoka villages in Kongwa district, Dodoma region. M.S. thesis, Mzumbe University, Morogoro, Tanzania.

Mwamfupe, D. (2015). Persistence of farmer-herder conflicts in Tanzania. International Journal of Scientific and Research Publications, 5(2).

Ndelwa, L. L. (2014). Role of water user associations in the management of water use conflicts: A case of Ilonga sub-catchment in Wami-Ruvu Basin, Tanzania. M.S. thesis, Sokoine Univ. of Agriculture, Morogoro, Tanzania.

Ngowi, N. J., \& Makfura, E. (2015). Descriptive analysis of sub catchment associations' contribution to management of water use conflicts in the Great Ruaha River of southern Tanzania. WIT Transactions on Ecology and the Environment, 196, 115-125.

Nkhambaku, W. E. (2014). "Assessing the role of local authority institutions on peasantspastoralists land use conflict mitigation in Tanzania: a case of Kishapu district," M.S. thesis, The Open University of Tanzania, Dar es Salaam, Tanzania.

Pegg, S. (2003). Globalization and natural-resource conflicts. Naval War College Review, 56(4).

Richards, P. (2001). Are "forest" wars in Africa resource conflicts? The case of Sierra Leone. In N. L. Peluso and M. Watts (Eds.), Violent environments (pp. 65-82). Ithaca: Cornell University Press.

Shepard, D. (1968). A two-dimensional interpolation function for irregularly spaced data. Proceedings of the 1968 23rd ACM national conference. New York. https://doi. org/10.1145/800186.810616

Shishira E. K., \& Yanda, P. Z. (1997). Kilosa district: Land use and natural resource assessment. Report prepared for Kilosa District Council//rish Aid, Institute of Resource Assessment Dar es Salaam.

UNEP. (2009). From conflict to peacebuilding: The role of natural resources and the environment. United Nations Environment Programme UNEP, Nairobi.

Zoomers, A. (2010). Globalization and the foreignisation of space: seven processes driving the current global land grab. The Journal of Peasant Studies, 37(2), 429-447. https://doi.org/10.1080/03066151003595325 